\title{
Why are occupational safety crimes increasing?
}

Felipe Estrada, Karin Bäckman, Janne Flyghed and Anders Nilsson Department of Criminology, Stockholm University

Published in Journal of Scandinavian Studies in Criminology and Crime Prevention, vol 15: 3-18.

\section{Introduction}

Despite the fact that occupational safety offences constitute a form of crime that produce serious consequences for both individuals and society at large, they are given relatively little consideration either in social debate or in the research literature. One reason for this is that occupational safety crimes rarely fit the stereotyped image of crime and criminals (Bergman 1994:97; Alvesalo \& Whyte 2007; Tombs \& Whyte 2007). The businesses and workplaces where these crimes occur are rarely linked to anything criminal or negative, but are rather viewed as legitimate organisations that perform important functions for society. Thus both the victims and the perpetrators differ from the picture that is portrayed for example in relation to "street violence" (Tombs 1999:85; Croall 2004, Machin \& Mayr 2012). The fact that occupational safety crime produces serious consequences and is at the same time underresearched makes it important to devote more attention to this type of crime.

In 1983, Statistics Sweden began to produce statistics on the number of reported occupational safety offences. Since this time, the number of such reported offences has varied dramatically (Figure 1). The trend is characterized by varying levels and directional trends and by a clear shift in the structure of the reported offences. During the 1990s, the level of reported crimes was remarkably low by comparison with both the preceding and the subsequent period. It can also be seen that the structure of reported safety crimes has shifted markedly. During the 1980s, the majority of reports offences related to offences against the Work Environment Act while today the offence category Causing bodily injury accounts for almost three-quarters of the reported crimes. This naturally raises the question of how such dramatic variations - in both the level and the structure of reported offences - might be understood. 


\section{Figure 1. About Here}

The most natural explanation, which may be said to reflect an objectivist understanding of social problems (Estrada 2001), would be that the shifts reflect changes in the actual occurrence of different types of occupational safety crime. One reason might be changes in the work environment. The increase in reported offences witnessed over recent years has been linked, for example, to increased time pressures, increasingly complex roles for those responsible for coordinating the work of businesses (Brå 2008) and to the number of overseas workers having increased since Sweden's accession to the EU, which is assumed to have led to language difficulties and to have resulted in an inadequate knowledge of occupational safety issues (see Arbetsmiljöverket 2012b).

The major shifts noted in reported offences further indicate that the statistics have been affected by factors that do not solely relate to the number of occupational safety crimes that are committed. An alternative, or complementary, explanation could therefore focus on possible changes in routines relating to how occupational safety crimes are defined and detected. On the basis of a view that statistics are a social product, it becomes possible to emphasise explanations that proceed from a social constructivist perspective (Estrada 2001). An act that is not reported can never find its way into the statistics. Furthermore, registered offences are also influenced by the work routines of various agencies, the control functions that exist in society and the way legislation is formulated. Thus statistical increases need not mean that the actual number of occupational safety crimes has increased, but may rather be a result of changes in reporting propensities or of more effective control measures.

Currently, our knowledge about the nature of the incidents that crime statistics classify as occupational safety crimes is rather poor. We know even less about whether this has shifted over time. This makes it difficult to determine how the trends described should be understood. The objective of this article is therefore to analyse the structure of, and trends in, reported occupational safety crimes. The central focus is directed at analysing how we might understand the substantial increase in the number of reported offences witnessed during the first decade of the $21^{\text {st }}$ century. 


\section{Prior research}

\section{What are occupational safety crimes, and how are they regulated in Sweden?}

In Sweden, an average of one person per week dies as a result of some form of work-related accident, and approximately 30 people per day are so seriously injured that it leads to a period of seek leave of at least 14 days (Arbetsmiljöverket 2012). Far from all of these incidents involve occupational safety crimes. Determining whether or not an incident should be regarded as an occupational safety crime or a workplace accident is difficult from both legal and scientific perspectives. Stated briefly, occupational safety crimes may be described as breaches of law, by an employer, which either produce or have the potential to produce injury, illness or death as a result of work-related activities (Steinberg 2006). In the case of accidents at work, it is not the accident itself that may constitute a crime. Instead the criminal responsibility follows from the employer not having prevented the accident, or at least not having done what might reasonably have been required of him in this regard.

In Sweden, occupational safety offences are regulated in part in the penal code, in part in the Work Environment Act. The offence categories that are by far the most numerous among occupational safety offences, are: Causing an employee's death (Penal Code 3:7), Causing bodily injury or illness to an employee in connection with a workplace accident (Penal Code 3:8), Creating danger to an employee (Penal Code 3:9) and offences against the Work Environment Act (WEA).

Unlike the Penal Code, the Work Environment Act (1977:1160) is formulated as a piece of framework legislation. The nature of a framework law means that the legal content of the Act is not determined in advance, but is rather developed through the Act's application in practice. This is not to say that the Work Environment Act sets no definite actual or normative limits in relation to employers' obligations (Ahlberg, Ericson and Holmgren 2008). Furthermore, the Work Environment Act is supplemented by the Work Environment Ordinance, and by a large number of regulations issued by the Work Environment Authority. Overall, this complexity means that the field of occupational safety is complicated from a legal perspective. 
In order to achieve a more effective control of the work environment among employers in Sweden, the courts have been able since 1986 to award corporate fines. This sanctioning alternative was rarely used, however, until a few years into the new millennium. In 2006, the opportunities for awarding corporate fines were extended (SOU 2011:57, 71).

The Work Environment Authority is the supervisory agency with responsibility for ensuring that businesses follow the Work Environment Act. If the agency in the course of its inspections detects irregularities that constitute criminal offences, the police may be called in. The agency may also issue prohibition orders against an employer conducting certain types of work, and orders to seal off or suspend activities at a given workplace. This means that the number of reported offences against the Work Environment Act is in part dependent on the actions and measures taken by the Work Environment Authority.

\section{Visible occupational safety crime - the result of a selection process}

There are three principal ways in which a crime may come to the attention of the police. It may be reported by the victim, by witnesses or by someone else who was present; it may be detected by the police or it may be reported by another agency, such as the Work Environment Authority. People tend to first and foremost report incidents that are perceived to constitute crimes and that have also resulted in serious injury either to themselves or to others (Brå 2008). If incidents are perceived to constitute accidents rather than crimes, they are therefore less likely to come to the attention of the criminal justice system. In the case of occupational safety crimes, the victims is furthermore most commonly an employee, and the suspected offender is often the victim's employer. This relationship, characterised as it is by dependency, may be assumed to further reduce the propensity to report incidents to the police (Tombs 2000). For foreign workers, there is the additional factor that their stay in the country may be conditional upon their current employment, which makes it less likely still that occupational safety crimes will be reported (see Croall 2004).

Many of the offences against the Work Environment Act that are detected come to the attention of the criminal justice system as a result of workplace inspections conducted by the Work Environment Authority (Steinberg 2011). These inspections may either be planned in advance or may be the result of the Authority having received information about deficiencies 
in the work environment (Arbetsmiljöverket 2009). The number of occupational safety crimes that are detected is thus dependent on how the Authority conducts its work (Bergqvist 2007It is inevitable that the inspection activities of the Work Environment Authority are directed at businesses that are registered and known to the authorities. There is good reason to assume that these are more likely to abide by the legislation than businesses operating in the grey and black sectors of the economy (Tombs \& Whyte 2007). Within the black economy, working conditions are worse (O’Neill 2003) and employees are not members of trade unions, which otherwise constitute an important actor in the work to ensure a good work environment (Tombs \& Whyte 2007). Nor is there a requirement for foreign companies working in Sweden to register themselves (Arbetsmiljöverket 2012b), which naturally reduces the likelihood that these companies become registered.

Thus the statistics include only a small proportion of all the incidents that could potentially be reported as occupational safety crimes. The extent of the hidden criminality in this area may increase or decrease over time (as a result of e.g. legislative changes, increased levels of attention or new work routines). Briefly stated, powerful increases or decreases in the number of reported offences need not reflect real increases or decreases in the number of crimes actually committed.

Against this background, an alternative explanation for the powerful increase in the number of reported occupational safety crimes may be formulated, which focuses on processes that have led to more incidents than previously being detected, defined and reported as occupational safety crimes. But why might we assume that this is what has happened?

\section{Collaborative and penal models of regulation}

The legal regulation of occupational safety offences may be broken down into two principal ideal types of approaches (see for example the debate between Hawkins 1990, 1991 and Pearce \& Tombs 1990, 1991). The collaborative model is characterised by consensus and negotiation within the context of a regulatory framework law. The advocates of this model espouse a substantial faith in businesses' capacity to self-regulate, they view information and education as effective preventive measures, and they express a desire for as little involvement as possible from the criminal justice system. They have a positive view of the opportunities for negotiation that are characteristic of the use of framework legislation. The punishment model represents a much more sceptical approach to the idea that businesses will take 
expensive measures in the absence of considerable pressure. The advocates of this model argue that clearer legislative regulation is required in order to deal with occupational safety crimes, and they are therefore in favour of a juridification of the room for interpretation associated with framework legislation. The legislation intended to combat occupational safety crime lies between these two extremes.

Over recent years, there has been an expansion in the use of elements from the punishment model, e.g. in the UK, where businesses can now be charged with manslaughter (Almond \& Colover 2010). A similar trend can also be seen in other European countries, such as Italy, France, Germany and Finland (Almond \& Colover 2010; Weigend 2008:932; Gray 2006). Traces of both approaches can also be found in the Swedish legislation; i.e. indicating both a belief in the ability of businesses to self-regulate and retaining the opportunity to apply criminal justice measures. It is reasonable to assume however, that the Swedish tradition of negotiation and consensus has led to a relatively restrained use of the criminal justice approach. The major part of the occupational safety work conducted in Sweden takes place at the local level in the form of a collaboration between employers and employees and their trade union organisations. This collaboration between employers and employees in locallybased occupational safety work has been described as "one of the central pillars on which the work environment legislation rests" (SOU 2009:97, 28, see also SOU 2011:57, 14).

It is widely acknowledged that politicians may turn to legislation as a means of showing that they are taking problems seriously. A recent British study, for example, found that the criminal justice model is perceived as sending a more direct and clearer signal to businesses (Almond \& Colover 2012:1009). The need to be seen to be sending such signals may become pressing if a certain incident attracts attention and becomes the subject of public debate (O’Neill 2003:33; Almond 2007:289). In such situations it is possible that the need for symbolic action intensifies the focus of legislators on criminal justice measures to combat occupational safety crimes. In these contexts, arguing for the use of the collaborative model sends a weaker signal, which makes it a less attractive political alternative. One possible explanation for the increase in the number of occupational safety crimes noted in the statistics may thus be a change in the way the authorities deal with this type of offences. In other words, the balance between the collaborative model and the punishment model may have shifted towards the latter, reflecting a process of increased juridification. 


\section{Data and methods}

In order to describe the trend in occupational safety crimes, we have analysed crime statistics relating to the number of reported offences. In addition, we have also examined alternative indicators such as data on the number of deaths that occur at work, police-registered "accidents at work that do not involve a suspected crime" and incidents and accidents reported to the Work Environment Agency. Some of these statistics have not previously been available, and the project has therefore requested special excerpts of raw data from the relevant statistical databases.

Statistics relating to injuries and accidents at work is used as an indicator of risks in the work environment. Section 2 of the Work Environment Ordinance (1977:1166), requires employers to report all serious incidents and accidents to the Work Environment Authority. This reporting requirement does not mean that the statistics actually include all serious incidents and accidents (see SOU 1988:3). Deaths that occur during time spent at work are as a rule reported to the Work Environment Authority. There is a dark figure, however, comprised of those incidents that do not immediately result in death. Besides studying accidents or incidents that have been reported to the Work Environment Authority (so-called Section 2 reports) we have also utilised the Information System for Occupational Accidents and Workrelated Diseases (ISA). The ISA has been compiled since 2001 by the Work Environment Authority on the basis of the work-related injuries dealt with by the Swedish Social Insurance Agency. The ISA data are naturally also subject to a dark figure (Sundström-Frisk \&Weiner 2004:91) which may be assumed to be larger with regard to less serious incidents.

In order to develop a clearer picture of the type of incidents that are reported as occupational safety offences, police reports, which contain a description of the reported offence, and court judgements have been collected for the period 2006-2010. We asked each of Sweden's police authorities to compile a list of all reported occupational safety crimes for the years 2006 and 2010. The police authorities were then asked to sort the cases by the date of the report and to select every other report from 2006, and every third from 2010. The term police report here refers to the written report, including the offence description, and the form "Notes, accident at work". All of the country's police authorities have submitted the requested reports. A very small number of the offence reports were not sent by the police authorities, since they involved cases where the justice system is still in the process of investigating the reported 
incident. As a result, the missing data do not affect the representativeness of the material. The textual content of the police reports have been made numerical by applying a coding manual. Most of the coding was straightforward. However the information on the injured party's injuries contained in the police reports was far from exhaustive. The nature of the injury is often unclear at the time the report is filed. The victim may for example be on the way to hospital in an ambulance and may not yet have been examined. In our classification of the injuries we have utilised the available information that describes the incident and possible injuries. We have proceeded on the basis of a cautious "at least this serious" principle and have classified injuries in the least serious category that appears reasonable on the basis of the information included in the report. Reliability controls where performed and the manual were revised to increase the validity of coding. The final data set is comprised of 1039 police reports (375 from 2006 and 664 from 2010). ${ }^{1}$

The data provide us with an opportunity to provide representative and more detailed descriptions of the incidents that have been registered in the crime statistics. This allows us to come further towards an understanding of what may lie behind the substantial increase in the number of reported occupational safety crimes witnessed since the beginning of the new millennium.

\section{Analysis of the trend in occupational safety crimes}

\section{Trends in reported occupational injuries and offences reported to the police}

Although far from all the injuries and incidents that occur at work constitute crimes, and thus objects for the work of the justice system, it is of interest to compare the number of serious injuries reported to the Work Environment Authority with the number of occupational safety offences registered by the police as "Causing bodily injury" (Penal Code 3:8). Throughout the period 1990-2011, the number of offences registered by the police was significantly smaller than the number of reported injuries (Figure 2, note that the police reported offences should be read on the basis of the right-hand axis). On average there were approximately 30 occupational injuries reported to the Social Insurance Agency that led to at least 14 days sick leave (ISA) for each crime reported to the police. The difference between the two series has

\footnotetext{
${ }^{1}$ A more detailed description of the data can be found in Bäckman et al. 2013.
} 
declined substantially during the 2000s. As can be seen from the figure, this trend is due to both a decline in the number of reported injuries (by a third) and a dramatic increase in the number of offences reported to the police.

Another data series that follows a completely different trend to that of the number of injuries that have led to at least 14 days sick leave is that relating to the so-called Section 2 reports. The number of serious incidents and accidents that employers have reported to the Work Environment Authority in accordance with Section 2 of the Work Environment Ordinance (1977:1166) has increased substantially between 1998 and 2010 (from approximately 3,800 to 12,500). Thus during the 2000s there has been an increase in both the number of Causing bodily injury offences reported to the police and the number of Section 2 reports to the Work Environment Agency. These increases have occurred in parallel with a decline in the number of reported incidents involving injuries that have resulted in a period of at least two weeks' sick leave.

\section{Figure 2 About here.}

In order to understand what the occupational injury statistics show, we require, knowledge both about the way the statistics are constructed and about external factors that affect the level of these statistics. One thing that is clear is that the decline in reported injuries in the ISA data does not necessarily mean that the work environment has improved over the last ten years and that the number of injuries has thus actually declined. The dramatic decline in the number of work-related accidents at the beginning of the 1990s was influenced by a range of different factors, including amongst other things changes in compensation regulations, a stricter assessment of work-related injuries and the powerful economic decline experienced at the time (Sundström-Frisk \& Weiner 2004:92). Further, the decline witnessed since 2003 may be linked to changes in the right of employees to receive compensation for work-related injuries. After 2003, a report was no longer required in order to receive compensation, which may be assumed to have affected the propensity to make the reports that are recorded in the ISA. In addition, the statistics only include injuries to employees of businesses with a Swedish organisation number. To the extent that increasing numbers are working in foreign businesses that are active in Sweden, this may be assumed to increase the size of the dark figure. 
In the same way, the increase in the number of reported offences or Section 2 reports need not mean that the actual number of occupational safety crimes has increased. Instead this trend may, for example, be due to improvements in the work of the inspection authorities and the justice system. In the years 1984-85, it was estimated that only a few percent of all workplace accidents that resulted in sick leave were reported to the then Labour Inspectorate by employers (SOU 1988:3 p. 48). Given this very low reporting propensity on the part of employers, there is much to suggest the need for explanations that focus on an increase in the level of attention focused on employers' obligations to report work-related injuries to the Work Environment Authority.

\section{Work-related deaths}

The trend in the number of work-related deaths is of course important in and of itself, but it may also be seen as an indicator of the trend in the level of serious hazardous conditions at work (Hutter \& Lloyd-Bostock 1990). Accidents resulting in death first and foremost occur in male-dominated sectors such as agriculture, manufacturing, forestry, construction and transport (Arbetsmiljöverket 2012). . During the 1980s, approximately 150 such deaths were reported per year, whereas this figure has declined to a level of approximately 60 incidents per year during the 2000s (Figure 3).

Looking to the number of deaths reported to the police, a decline is also visible during the 1980s and 1990s (from approximately 20 to 10 reported offences per year). During the 2000s, however the number of deaths reported to the police has increased. This means that the number of deaths reported to the police lies at a completely different level, but also follows a different trend, during a large part of the period under study.

Today we have a situation where the majority of accidents resulting in death are initially defined by the justice system as cases of Causing death, which was not at all the case in the 1980s and 1990s. This change may be viewed as an indication that there has been a shift in the way the police and the justice system define the most serious work-related injuries. The propensity to register these incidents as crimes has increased.

Figure 3 about here 


\section{Work-related injuries that the police do not register as crimes}

Up until the end of 2012, the incident code "Workplace accident with no suspected offence" was to be used in those cases where the police judged a work-related injury to have arisen in way that meant a criminal act could be excluded as a possibility.

\section{Figure 4. about here}

In Figure 4 we compare the trends in those cases that the police have coded as "workplace accidents" with those incidents that have been registered as cases of Causing bodily injury or illness. As was noted earlier (Figure 1 above), the number of occupational safety crimes reported to the police was very low during the1990s. The opposite is the case in relation to the incidents that the police have chosen to register as workplace accidents. In effect this means that a substantial majority of all workplace injuries were registered as accidents during the 1990s and not as crimes. At the beginning of the 2000s, a shift takes place, since we can see both a powerful increase in the number of reported offences, while in parallel, the number of registered accidents is halved. During the years 2009-2011, it is more common for the police to register an injury as a Causing bodily injury offence than as a "workplace accident with no suspected offence".

There is also a code (also in use since 1991) that the police may choose to employ in relation to work-related deaths where there is no suspicion of a crime. In exactly the same way as with workplace accidents that have not resulted in death, the number of registered lethal accidents was highest during the 1990s, and then declined successively during the 2000s. The trend for reported incidents that have been registered as crimes (Causing an employee's death) has gone in the opposite direction.

\section{Figure 5 about here}

On the basis of Figures 4 and 5 it would appear that the police have changed their routines for registering occupational safety crimes during the 2000s. The increase in the number of 
reported offences thus appears to be the result of an increased propensity on the part of the police to register workplace injuries under a crime code rather than an accident code.

\section{Content analysis of police reports}

We have noted that there has been a dramatic increase in the number of occupational safety crimes registered by the police, however, we lack any more detailed knowledge about the types of incidents that might explain the increase seen in the statistics. By analysing the information written in police reports, we are able to look for answers as to what characterises the incidents dealt with by the justice system.

Since there has been a marked increase in the number of reported offences, finding a smaller proportion of a certain type of offence in 2010 does not necessarily mean that the number of incidents of this type has declined. ${ }^{2}$ The reason for focusing on proportions is that we wish to identify any structural changes that have occurred in relation to occupational safety crimes and also the type of factors that may lie behind the increased inflow of reports registered by the police.

\section{Who reports occupational safety crimes, and where do they take place?}

As expected, the Work Environment Authority is behind the majority of the reports that relate to offences against the Work Environment Act (Table 1). This is true both for 2006 and 2010. There have been substantial changes, however, as regards who the Penal Code offences have been reported by. The proportion of registered crime reports initiated by the police or someone from the business in question has increased while (together they account for 55 percent of the increase in the statistics) at the same time the proportion of reports made by healthcare staff has declined. ).

\section{Table 1 about here}

\footnotetext{
${ }^{2}$ Since we have collected every other police report from 2006 and every third report from 2010, a comparison of the numbers of reported offences would be misleading (and would underestimate the size of the increase that has occurred). In those cases where we state how large a proportion of the increase different categories account for, we have therefore multiplied the number of reports from 2010 by a factor of 1.5 (in order to produce a figure corresponding to a sample of every other police report from 2010 as well).
} 
Of the crime victims described in the police reports, 90 percent are male and 10 percent female. The mean age lies at around 40 years. Between 2006 and 2010, there is an increase in the proportion of incidents involving young victims (data not presented in table. See however Bäckman et al. 2013). A larger proportion of the incidents reported to the police have occurred in occupations related to construction, transport and warehousing and manufacturing. Together these sectors account for two-thirds of the reports. Among the Penal Code offences, which primarily relate to incidents in which someone has been injured, there are no major changes in this structure between the two years. Among the reports relating to offences against the Work Environment Act, however, there are visible changes over time. The proportion of incidents relating to the construction sector declines, whereas the proportion of reports accounted for by both the transport sector and manufacturing increase markedly. Since the reported injuries do not follow this pattern, the trend is likely to be linked to the way in which inspection activities have been conducted (see further Bäckman et al. 2013 p.44f).

\section{What types of injury are described in the reports?}

The most common incidents described in the police reports from both 2006 and 2010 involve the injured party having been injured by an object by which he or she has been hit or crushed. It may, for example, have been a falling tree, an object that has fallen over or dropped onto the injured party, e.g. when the individual in question was removing items from shelves in a warehouse, or that the injured party has been injured by scaffolding. Approximately onequarter of the reports relate to an individual having falling, often from a considerable height, e.g. from a roof, a ladder or from scaffolding. Two other common categories of incidents relate to individuals having been injured by machines or tools. Between the years 2006 and 2010, there are only minor changes in the types of incidents described in the police reports. The increase in the number of such reports cannot thus be linked to the emergence of a new type occupational safety incident (see further Bäckman et al. 2013 p. 46f).

Approximately one-fifth of the reported occupational safety crimes involve incidents in which no injury was sustained (Table 2). These cases largely involve incidents where there was a risk that an injury could have occurred as a result of an employer not having inspected a machine, for example, or because the business had omitted to have employers working with 
thermosets examined by a doctor. These reports are often made subsequent to inspections by the Work Environment Authority. The fact that this type of incident has almost been halved in proportional terms is due, as was noted above, to the major increase noted in the number of Penal Code offences, which thus account for an increasing proportion of the registered incidents.

\section{Table 2 about here.}

The most common injuries described in the police reports involve different types of physical injury that have not been presented as serious in the incident description contained in the police report. These may be large bruises, sprains, small cuts or puncture wounds or other "injuries of a transient nature". Since this category of injuries is so large, the small proportional increase (from 42 to 49 percent of the injuries) nonetheless means that half of the increase in the number of registered police reports involve this type of injury.

The proportions of incidents that include information suggesting the presence of very serious injuries (such as serious burns, injuries to internal organs, loss of body parts or invalidity) and of incidents that involve deaths remain unchanged. Given the substantial increase in the number of reports, this finding is unexpected. These are precisely the type of incidents for which the reporting propensity would be expected to be high irrespective of the date at which they occurred, and they ought therefore to be less sensitive to changes in registration routines. Where increases in the number of violent crimes reported to the police have been studied, the proportion of incidents involving serious injuries has been found to decline significantly, with a much larger proportion of the increase thus being ascribed to incidents involving only minor injuries (see e.g. Estrada 2001). In concrete terms this means that there were a significantly larger number of offences involving deaths and serious injuries registered by the police in 2010. Given that these are very serious incidents that may be assumed to have been associated with a high reporting propensity both in 2006 and 2010, this finding might be interpreted as reflecting a real increase in serious incidents of this kind.

There are problems with such an interpretation however. Since the police have the opportunity to register these incidents as either accidents or crimes (see above), more of these incidents may have come to be registered as crimes at the same time as the propensity to report such incidents may have remained unchanged. Thus what has changed is the way the 
incidents are registered, and not the propensity to report. In Figures 4-5, we showed that this tendency was very clear during the 2000s, both for cases involving personal injuries and for work-related deaths. This means that overall, there is much to indicate that the increase in the number of Causing bodily injury to an employee offences registered by the police is due on the one hand to an increasing number of less serious incidents being reported (by the police and businesses), and on the other to a redefinition of such incidents on the part of the police, from accidents to crimes.

\section{Concluding discussion}

The research literature describes two principal approaches to the regulation and prevention of occupational safety offences. The one focuses on punishment, the other on collaboration. From the perspective of the collaborative model, occupational safety offences are primarily caused by ignorance or carelessness. From the perspective of the punishment model, such offences are instead the result of businesses consciously neglecting to take the measures necessary to ensure a safe work environment for economic reasons. One fundamental difference between these two strategies for combating occupational safety crimes is that the collaborative model desires to balance competing interests on the basis of consensus, whereas the punishment model desires to juridify the issue by means of a more intense focus on criminal law, thus preserving the distinction between right and wrong in absolute terms. It is difficult, both in legal and scientific contexts, to determine the extent to which an incident should be viewed as an occupational safety crime or a workplace accident. We would argue that one of our central findings is that the distinction between these two alternatives has shifted during the first decade of the $21^{\text {st }}$ century, and that we are witnessing a trend towards a greater level of juridification.

Determining what governs the trend in reported offences is naturally not entirely straightforward. At the same time, doing so is important in order to be able to determine whether different types of preventive measures and the work of public sector agencies is having the desired effect. In order to be able to interpret trends in occupational safety crimes that are known to the relevant authorities we have employed material from a range of different data sources. During the 2000s, the number of occupational safety crimes registered by the police (first and foremost in the form of Causing bodily injury) increased dramatically. Our interpretation of this trend is that it is primarily due to a shift in definitions and in the 
reactions of the authorities (which would invoke a social constructivist explanation) rather than to a powerful increase in the number of actual crimes committed (which would reflect a more objectivist interpretation). There are a number of factors that support this interpretation. There is a substantial amount of room for discretion when the police decide how incidents should be classified (as crimes or accidents). During the 2000s, we have shown that the police have increasingly chosen not to use of the code for workplace accidents in favour of the use of crime codes.

The increase in the number of incidents reported to the police is for the most part explained by an increase in the number of reports relating to Causing bodily injury. These incidents are increasingly often being reported either by the police or by businesses. Our analysis shows that a large proportion of the reported incidents have taken place in largely male-dominated sectors. The substantial increase in the number of police reports has not produced a change in the structure of the incidents reported. What has changed between 2006 and 2010, however, is the nature of the injuries involved, with the proportion of physically non-serious injuries having increased. One possible interpretation is therefore that these are incidents that would previously have been registered as "workplace accidents with no suspected offence". Thus the increase in the number of cases of "Causing bodily injury" registered by the police is linked on the one hand to an increase in the reporting of less serious incidents, and on the other to a shift in the way the police define reported incidents, registering them as crimes instead of as accidents.

Thus taken together, our results indicate that reported incidents that are not defined as criminal acts are undergoing a substantial decline, at the same time as the number of cases defined as crimes and the number of reports to the Work Environment Authority regarding serious incidents and/or accidents is increasing. This shows that registered occupational safety offences should first and foremost be viewed as a measure of the work of the authorities, rather than as an indicator of real crime trends (see also Bergqvist 2007:98). In this sense, one could choose to view the increase in offences registered by the police as a success for those who advocate the punishment model and a juridification of injuries that occur at work.

\section{Crime prevention relevance}


The indistinct line between accidents and crimes constitutes a problem for the preventive work intended to combat occupational safety offences. In the context of the public debate, these incidents are rarely perceived to constitute crimes, the injured party is not described as a crime victim, and the perpetrator rarely fits the prevailing stereotypes of offenders (Bergman 1994:97; Alvesalo and Whyte 2007; Tombs and Whyte 2007;). It is possible that this may be in the process of changing. We have seen signs that, at least in the agencies of the justice system, there is an ongoing tendency towards juridification. That is to say that we are witnessing a process whereby increasing numbers of incidents are being viewed as crimes that should be investigated and punished by the criminal justice system instead of being dealt with as accidents that should be prevented at the workplaces themselves. Interestingly, this punitively focused trend "out in the field" is at odds with the tone of the prevailing political debate about offences against the Work Environment Act and how these should be regulated.

Two recent government inquiries, Market-oriented means of governance in the work environment field and More effective sanctions in the area of the work environment and working hours, both emphasise the collaborative model. The latter inquiry, for example proposes a decriminalisation of certain offences against the Work Environment Act that are currently prosecutable, while the first examines whether work conducted at businesses in the field of the work environment may become a means of competition between businesses. These proposals are very clearly in line with those advocated by representatives of the collaborative model. Through education and information, businesses and employers are viewed as being able to conduct independent preventive work in order to create a good work environment. At the same time, these inquiries also include elements that indicate the presence of a punishment mentality. Financial sanctions or fines can certainly be perceived by individual businesses as penalties that are every bit as severe as a criminal justice solution. Thus the conflict between the collaborative and the punishment models remains very much alive.

In conclusion we would like to emphasise that the very clear definitional shift (from accidents to crimes) that we have noted does not appear to have led to a corresponding expansion in what is reported as occupational safety crimes. Thus it is not the case that new types of incidents with different types of crime victims have come to be viewed as crimes. By contrast, studies of violence in other contexts, have found precisely this kind of expansion in what is 
viewed as a reportable offence. Estrada et al. (2010), for example, show that an increase in the level of attention focused on threats and violence at work has been followed by both a definitional shift and an expansion in the range of work-related violent incidents that are regarded as being reportable to the police. This has led to the victimisation of women working in the care sector in particular becoming much more visible.

The increased inflow of reported occupational safety crimes has not however led to increasing numbers of women becoming visible as victims. An overwhelming majority of the reported incidents continue to relate to accidents in traditionally male occupations. We have found very few reports that relate to sickness or ill health, despite the fact that the declaratory paragraph of the Work Environment Act notes that "The purpose of the Act is to prevent illhealth and accidents at work and also to otherwise achieve a good work environment." At the same time, we know that work-related ill-health is more widespread among women than among men (Estrada et al. 2010). One explanation for this paradox is that occupational safety crimes have in practice come to relate to incidents that involve some form of accident. Steinberg (2011) has also shown that the inspections of the Work Environment Authority tend to be directed at male-dominated sectors and that the legislation, including various regulations, is more extensive and clearer in relation to these sectors. The Work Environment Act and its application by public sector agencies clearly favours those employed in the traditional male sectors rather than those traditionally associated with a largely female workforce.

The focus in the present study has been on registered crime, i.e. events that come to the attention of the authorities. This is obviously a limitation. To gain further knowledge, and capture work related injuries that are not reported to authorities, it may be fruitful to use victim surveys (there are currently no Swedish victim surveys that focus on occupational safety crimes) and/or information from the Swedish hospital discharge register. Finally, our main finding, that safety incidents are increasingly treated as crimes and not as accidents by the police, leads to several important questions regarding police discretion that we are not able to answer with the data we have access to in this study.

\section{References}


Ahlberg, K., Ericson, B. \& Holmgren, M. (2008). I lagens anda. En handbok $i$

arbetsmiljörätt. Stockholm: Prevent Arbetsmiljö i samverkan Svenskt Näringsliv, LO and PTK.

Almond, P. (2007). Regulation crisis: Evaluating the potential legitimizing effects of corporate manslaughter cases. Law and Policy. 29(3): 285-310.

Almond, P. \& Colover, S. (2010). Mediating punitiveness: Understanding public attitudes towards work-related fatality. European Journal of Criminology. 7(5): 323-338.

Almond, P. \& Colover, S. (2012). Communication and social regulation. The criminalization of work-related death. British Journal of Criminology. 52(5): 997-1016.

Alvesalo, A. \& Whyte, D. (2007). Eyes wide shut: The police investigation of safety crimes. Crime, Law and Social Change. 48(1-2): 57-72.

Arbetsmiljöverket (2009). Tillsynsserien. 4/2009. Regler för inspektion. Stockholm: Arbetsmiljöverket.

Arbetsmiljöverket (2012). Arbetsskador 2011. Rapport 2012:2. Stockholm: Arbetsmiljöverket.

Arbetsmiljöverket (2012b). Förstudie om det fortsatta arbetet med utländska företag och arbetstagare. Projektrapport 2012:5. Stockholm: Arbetsmiljöverket

Bergman, D. (1994). The perfect crime. How companies can get away with manslaughter in the workplace. Birmingham: West Midlands Health and Safety Advice Centre.

Bergqvist, M. (2007). Räkna med den ekonomiska brottsligheten. Om det kvantitativa studiet av ekonomisk brottslighet. PhD thesis. Stockholm: Department of Criminology, University of Stockholm.

Brottsförebyggande rådet (2008). Brottsoffers benägenhet att anmäla brott. Brå-rapport 2008:12. Stockholm: Fritzes.

Bäckman, K., Estrada, F., Flyghed, J., och Nilsson, A. (2013). Arbetsmiljöbrottens omfattning, struktur och utveckling. Rapport 2013:4, Arbetsmiljöverket.

Croall, H. (2004). Lurad och förgiftad - att avslöja utsatthet för ekobrott. Brå-rapport 2004:1. Stockholm: Fritzes.

Ericson, B. \& Gustafsson, K. (2002). Arbetsmiljölagen. Stockholm: Bokförlagetprisma.

Estrada, F. (2001): Juvenile Violence as a Social Problem. British Journal of Criminology, 41, 639-655.

Estrada, F., Nilsson, A., Jerre, K., and Wikman, S. (2010). Violence at work. The emergence of a Social problem. Journal of Scandinavian Studies in Criminology and Crime 
Prevention, vol 11:46-65.

Gray, G. (2006). The regulation of corporate violations. Punishment, compliance and the blurring of responsibility. British Journal of Criminology. 46(5): 875-892.

Hawkins, K. (1990). Compliance strategy, prosecution policy and Aunt Sally. A comment on Pearce and Tombs. British Journal of Criminology. 30(4): 444-466.

Hawkins, K. (1991). Enforcing regulation. More of the same from Pearce and Tombs. British Journal of Criminology. 31(4): 427-465.

Hutter, B.M. \& Lloyd-Bostock, S. (1990). The power of accidents: The social and psychological impact of accidents and the enforcement of safety regulations. British Journal of Criminology. 30(4): 409-422.

Machin, D. \& Mayr, A. (2012). Corporate crime and the discursive deletion of responsibility. Crime Media Culture 9:63-82.

Pearce, F. \& Tombs, S. (1990). Ideology, hegemony and empiricism. British Journal of Criminology. 30(4): 423-433.

Pearce, F. \& Tombs, S. (1991). Policing corporate skid rows. A reply to Keith Hawkins. British Journal of Criminology. 31(4): 415-426.

SOU 1988:3. Arbetsolycka - "Olycka” eller arbetsmiljöbrott?: betänkande av Arbetsolycksutredningen. Stockholm: Fritzes.

SOU 2009:97. Marknadsorienterade styrmedel på arbetsmiljöområdet: slutbetänkande av Styrmedelsutredningen. Stockholm: Fritzes.

SOU 2011:57. En bättre arbetsmiljö genom effektivare sanktioner: betänkande av Utredningen om Effektivare sanktioner på arbetsmiljö- och arbetstidsområdet. Stockholm: Fritzes.

Steinberg, M. (2006). Skyddsombudsrätt. Samverkan, ansvar och tillsyn. Stockholm: Norstedts Juridik.

Steinberg, M. (2011). Är arbetsmiljölagen sexistisk? In: Sandmark, H. (ed.) Perspektiv på kvinnors hälsa $i$ arbetslivet. pp. 221-254. Lund: Studentlitteratur.

Sundström-Frisk, C. \& Wiener, J. (2004). Vad säger arbetsskadestatistiken? In: Gustafsson, R. \& Lundberg, I. (ed.) Arbetsliv och hälsa 2004. pp. 75-99. Stockholm: Arbetslivsinstitutet.

Tombs, S. (1999). Health and safety crimes: (In)visibility and the problems of "knowing". In: Davies, P, Francis, P. \& Jupp, V. (ed). Invisible crimes: Their victims and their regulation. pp. 77-104. London: Macmillan. 
Tombs, S. (2000). Official statistics and hidden crime: Researching safety crime. In: Jupp, V., Davies, P. \& Francis, P. (ed.) Doing criminological research. pp. 64-79. London: Sage Publications.

Tombs, S. \& Whyte, D. (2007). Safety crimes. Cullompton: Willan.

Weigend, T. (2008). Societas delinquere non potest?: A German perspective. Journal of International Criminal Justice. 6(5): 927-945. 


\section{M11-2013: Figures and tables}

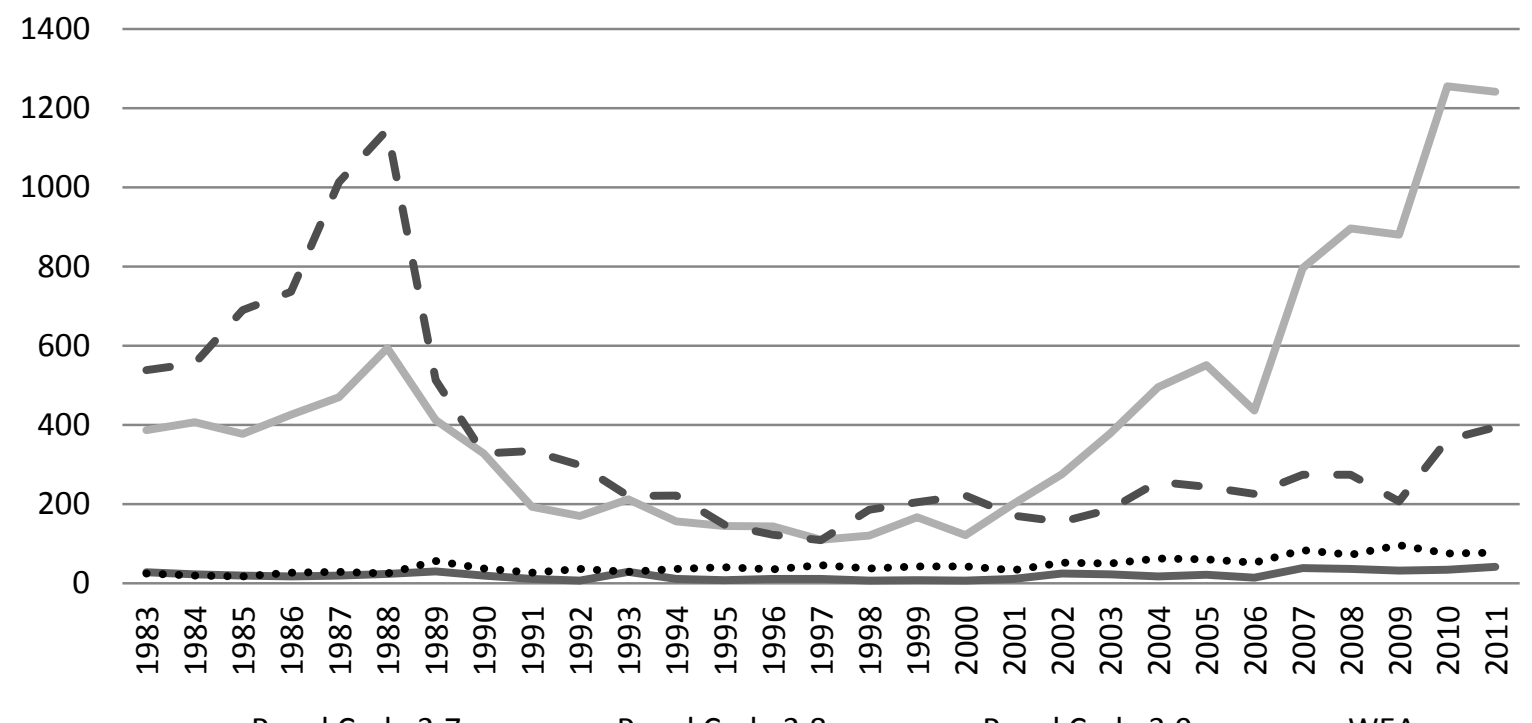

Figure 1. Reported offences in the form of Causing an employee's death (Penal Code 3:7), Causing bodily injury or illness to an employee (Penal Code 3:8), Creating danger to an employee (Penal Code 3:9) and offences against the Work Environment Act (WEA). 1983-2011. Source: Swedish National Council for Crime Prevention 


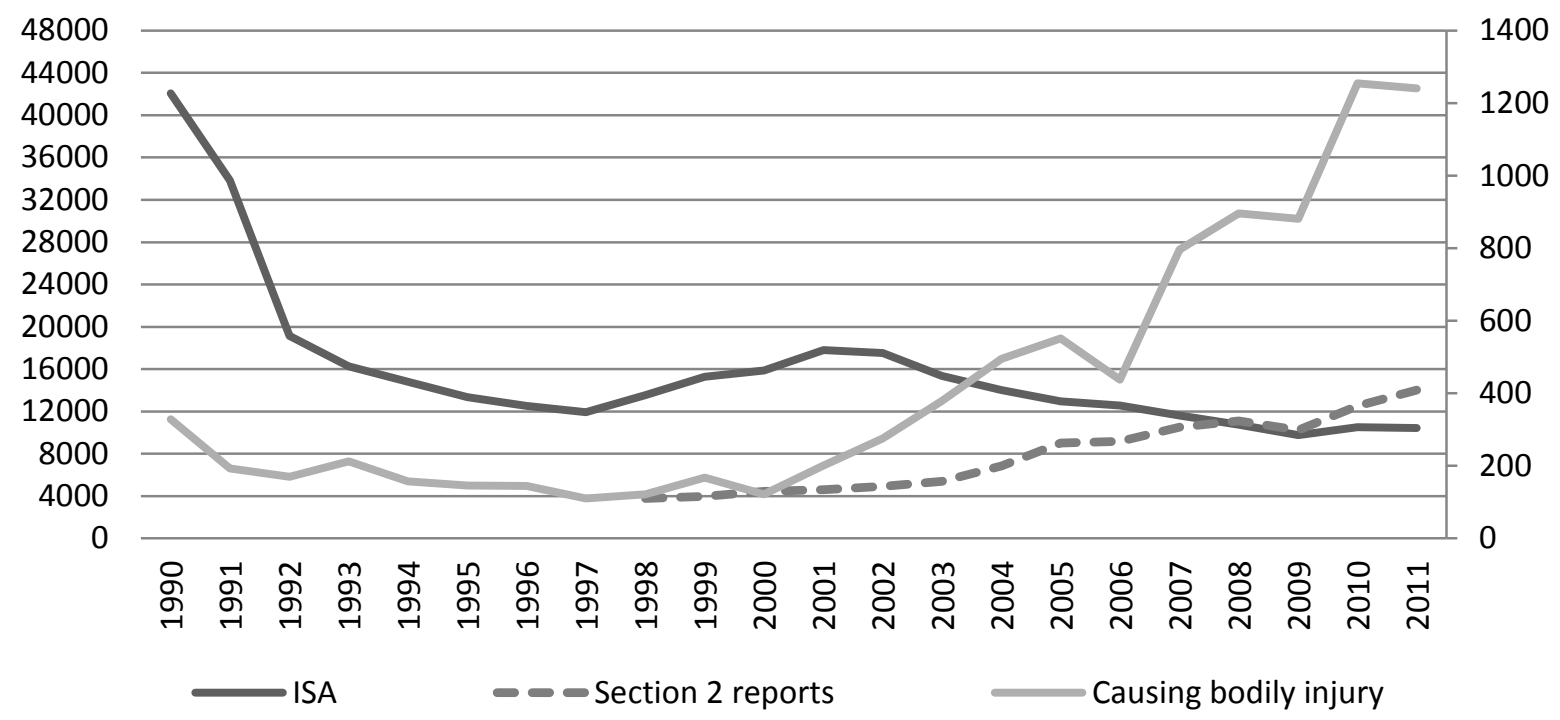

Figure 2. Left-hand axis: Number of registered workplace accidents resulting in at least two weeks' sick leave (ISA), incidents and accidents reported to the Work Environment Agency (Section 2 reports). Right-hand axis: Number of cases of Causing bodily injury or illness to employees reported to the police. 1990-2011. Causing bodily injury offences should be read using the right hand axis. Source: National Council for Crime Prevention and data specially requested from the Work Environment Authority. 


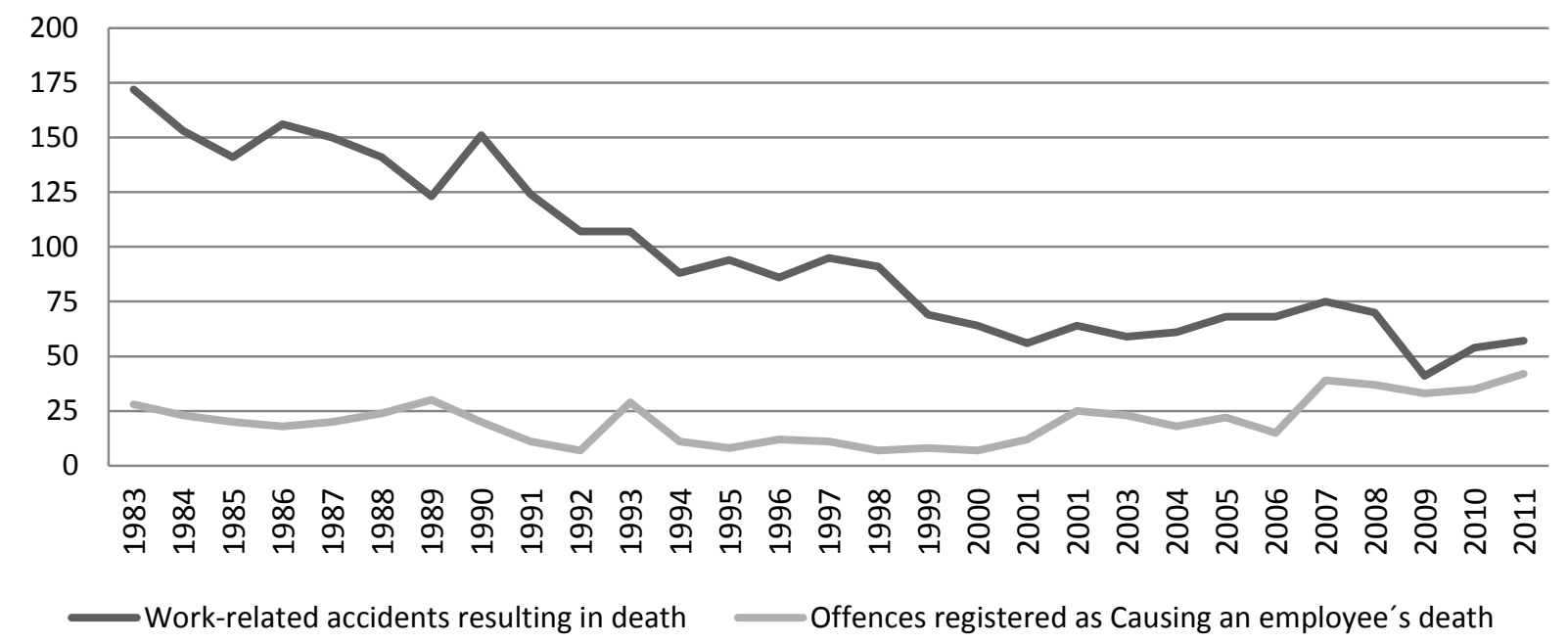

Figure 3. Number of work-related accidents resulting in death and number of reported offences registered as Causing an employee's death. (The deaths resulting from the Estonia catastrophe in 1994 are not included). Source: National Council for Crime Prevention and Work Environment Authority. 


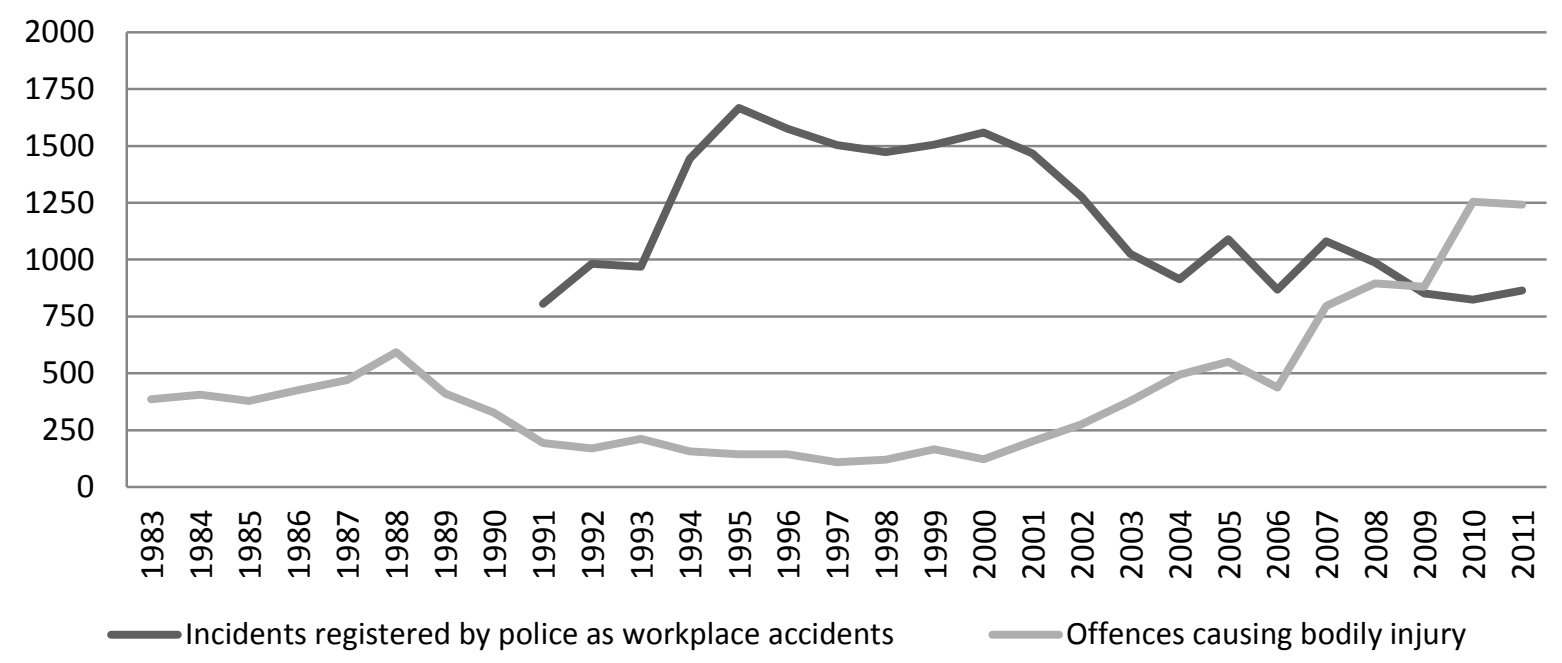

Figure 4. Number of registered offences of Causing bodily injury or illness to an employee and number of workplace accidents registered by the police. 1983-2011. Source: Specially compiled statistics provided by the National Council for Crime Prevention. 


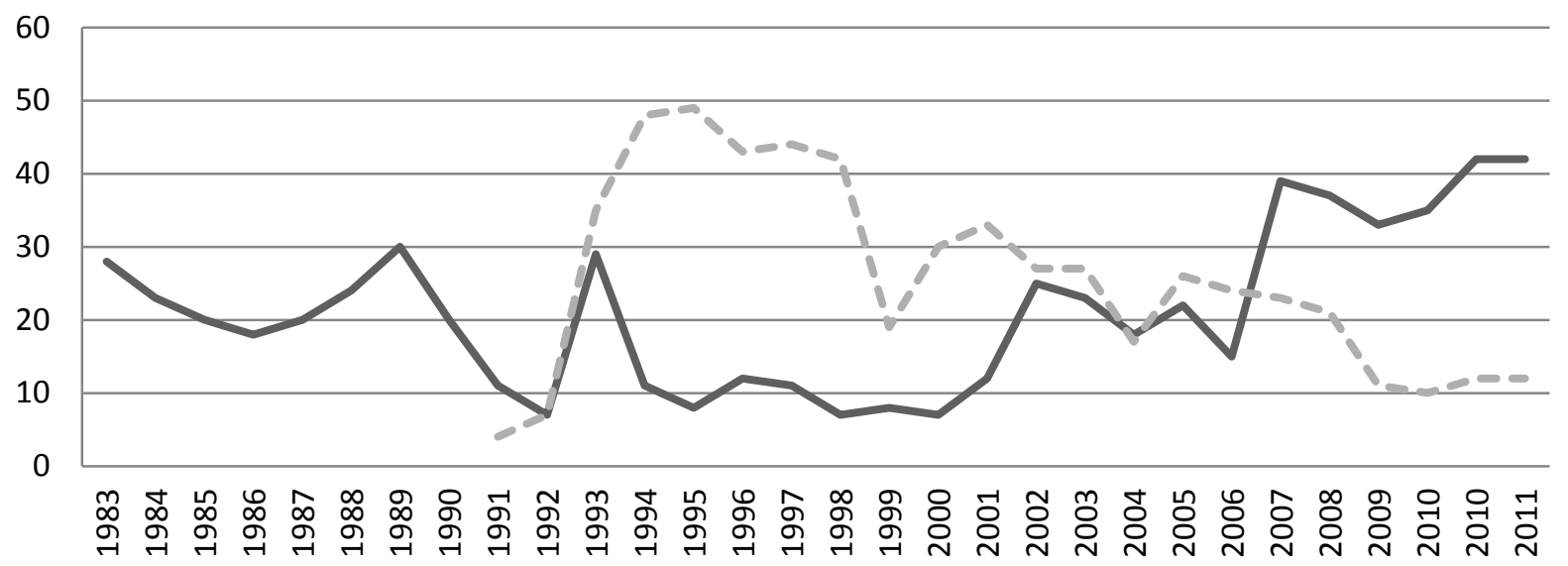

Registered offences: causing an employee's death $\quad--$ Lethal accidents registered by police

Figure 5. Number of reported Causing an employee's death offences and incidents registered by the police workplace accidents resulting death with no suspected offence. 1983-2011. Source: Specially compiled statistics provided by the National Council for Crime Prevention. 
Table 1. Who is registered by the police as having reported the incident? Every other police report from 2006 and every third from 2010. Proportion in percent (n).

\begin{tabular}{|l|r|r|r|r|r|}
\hline \multirow{2}{*}{ Who filed the report? } & \multicolumn{2}{|c|}{ Work Environment } & \multicolumn{2}{|c|}{ Penal code } & \multirow{2}{*}{ Total } \\
\cline { 2 - 5 } & 2006 & 2010 & 2006 & 2010 & \\
\hline Work colleague & 9 & 10 & 27 & 27 & 23 \\
\hline Police authority & 3 & 6 & 16 & $25^{*}$ & 18 \\
\hline Work Environment Authority & 60 & 55 & 1 & 2 & 15 \\
\hline Emergency services, healthcare staff & 5 & 1 & 24 & $15^{*}$ & 14 \\
\hline Business, foreman, manager & 3 & 6 & 17 & $24^{*}$ & 17 \\
\hline Injured party & 4 & $13^{*}$ & 9 & $3^{*}$ & 6 \\
\hline Health and safety representative, trade union & 7 & 4 & 0 & 1 & 2 \\
\hline Other (witness, relative) & 8 & 5 & 6 & 3 & 5 \\
\hline Total & 99 & 100 & 100 & 100 & 100 \\
\hline
\end{tabular}

$* \mathrm{p}<0.05\left(\mathrm{Chi}^{2}\right.$ test $)$ 
Table 2. Type injuries in occupational safety crimes registered by the police. Every other police report from 2006 and every third report from 2010. Percent (n).

\begin{tabular}{|l|l|l|l|}
\hline Incident & $\mathbf{2 0 0 6}$ & $\mathbf{2 0 1 0}$ & Total \\
\hline No physical injury, risk that an injury could have occurred & 25 & $14^{*}$ & 18 \\
\hline Physical injury & 42 & $49^{*}$ & 47 \\
\hline Serious physical injury & 24 & 27 & 26 \\
\hline Very serious injury, loss of a limb & 7 & 6 & 6 \\
\hline Deaths & 2 & 3 & 3 \\
\hline \multirow{2}{*}{ Total } & 100 & 99 & 100 \\
& $(346)$ & $(635)$ & $(981)$ \\
\hline
\end{tabular}

$* \mathrm{p}<0.05\left(\mathrm{Chi}^{2}\right.$ test $)$ 